\title{
Bacillus psychrophilus Larkin and Stokes 1967, a Later Subjective Synonym of Bacillus globisporus Larkin and Stokes 1967
}

\author{
H.-J. RÜGER AND G. RICHTER $†$ \\ Institut für Meeresforschung, Am Handelshafen 12, D-2850 Bremerhaven, Federal Republic of Germany
}

\begin{abstract}
The type strain of Bacillus psychrophilus Larkin and Stokes 1967 and that of Bacillus globisporus Larkin and Stokes 1967 are very nearly identical. Therefore these names are regarded as synonyms. On the basis of the rule of priority, $B$. globisporus is the correct name of this species. B. psychrophilus is thus a later subjective synonym of $B$. globisporus.
\end{abstract}

Four new psychrophilic Bacillus species, $B$. psychrosaccharolyticus, B. insolitus, B. globisporus, and $B$. psychrophilus, were named and described in 1967 by Larkin and Stokes (4).

$B$. psychrosaccharolyticus and $B$. insolitus can be distinguished from each other as well as from the other two species by their different nutritional and enzymatic properties and by the shape and arrangement of their spores. On the other hand, B. psychrophilus and B. globisporus are very closely related $(2,4)$. Gyllenberg and Laine (3), in a numerical taxonomy study of psychrophilic bacilli, were unable to separate these two species on the basis of their biochemical characters.

In our studies on halophilic bacilli, the type strains of B. psychrophilus and B. globisporus were included, but we could not detect any differences between them (6). Therefore, we attempted to determine whether a comparison of the cell wall compositions of these two strains would help clarify their relationship. The results of these examinations are presented here.

\section{MATERIALS AND METHODS}

Bacterial strains. The strains used in this study were Bacillus globisporus DSM 4 ( $=$ ATCC $23301=$ Larkin and Stokes W 25) and B. psychrophilus DSM $3(=$ ATCC $23304=$ Larkin and Stokes W 16 A). Both of these strains were designated by Larkin and Stokes

(4) as the type strains of their respective species.

Cultures of these strains were obtained from the Deutsche Sammlung von Mikroorganismen (DSM), Göttingen, Federal Republic of Germany.

Methods. The bacteria were cultivated in a modified ZoBell 2216 seawater broth (7), which consisted of: peptone, $5 \mathrm{~g}$; yeast extract, $1 \mathrm{~g}$; $\mathrm{FePO}_{4} \cdot 4 \mathrm{H}_{2} \mathrm{O}, 0.01$ $\mathrm{g}$; aged seawater, $750 \mathrm{ml}$; and distilled water, $250 \mathrm{ml}$ (pH 7.6).

The cultivation method, in which successively increasing amounts of the inoculum and of the culture medium were used to prevent the formation of spores,

$\dagger$ Present address: MILES-KALI-CHEMIE, D-3000 Hannover, Federal Republic of Germany. was as follows. Each of four test tubes containing $3 \mathrm{ml}$ of seawater broth was inoculated with a loopful of a young culture. After a few hours of incubation, the contents of each tube were transferred to a bottle containing $30 \mathrm{ml}$ of seawater broth and incubated overnight. From each culture, $30 \mathrm{ml}$ of broth was then used to inoculate $300 \mathrm{ml}$ of seawater broth in a 1-liter Erlenmeyer flask, and the flasks were shaken at 75 rpm for $48 \mathrm{~h}$ at $20^{\circ} \mathrm{C}$. The cells were subsequently harvested by centrifugation. This procedure yielded 2 to $3 \mathrm{~g}$ (wet weight) of cells. For the purpose of determining cell wall composition, the cells were then washed first in distilled water and subsequently in $96 \%$ ethanol. After washing, the cells were stored at $-20^{\circ} \mathrm{C}$ until use.

The cell wall analyses were performed as described by Richter (5), except that the cells of $B$. globisporus DSM 4 were extracted with $0.3 \mathrm{~N} \mathrm{KOH}$ and those of B. psychrophilus DSM 3 were extracted with $0.25 \mathrm{~N}$ $\mathrm{KOH}$.

\section{RESULTS AND DISCUSSION}

Larkin and Stokes (4) separated B. psychrophilus from $B$. globisporus on the basis of their distinctive behaviors with respect to nitrate reduction and their different abilities to ferment lactose, mannitol, and xylose. These species differed only slightly with respect to some other characters. Gordon et al. (2) subsequently examined the strains of Larkin and Stokes. The characters used by these two sets of authors to separate the two species are given in Table 1.

As shown by the data of Gordon et al. (Table 1), B. psychrophilus contains not only strains that ferment mannitol and xylose but also strains that do not. In this case, B. psychrophilus and $B$. globisporus overlap each other and thus cannot be differentiated solely on this basis.

According to Eiroma et al. (1), the deoxyribonucleic acid base compositions of the two type strains are different: the deoxyribonucleic acid of B. globisporus DSM 4 contained $36.8 \mathrm{~mol} \%$ guanine plus cytosine, whereas that of $B$. psychrophilus DSM 3 contained only $32.7 \mathrm{~mol} \%$ guanine plus cytosine. However, our examina- 
TABLE 1. Differentiation of B. globisporus and B. psychrophilus according to Larkin and Stokes (4) and Gordon et al. (2)

\begin{tabular}{|c|c|c|c|c|}
\hline \multirow{2}{*}{ Character } & \multicolumn{2}{|c|}{ B. globisporus, according to: } & \multicolumn{2}{|c|}{ B. psychrophilus, according to: } \\
\hline & Larkin and Stokes & Gordon et al. & Larkin and Stokes & Gordon et al. \\
\hline Cell size $(\mu \mathrm{m})$ & $0.8-1.1$ by $1.3-6.4$ & $0.8-1.0$ by $1.3-5.0$ & $0.8-0.9$ by $1.2-4.5$ & $0.8-0.9$ by $1.8-4.5$ \\
\hline Spore size $(\mu \mathrm{m})$ & $1.0-1.1$ & $\mathbf{n}$ & $0.9-1.3$ & $\mathbf{n}$ \\
\hline Motility & + & \pm & + & \pm \\
\hline $\begin{array}{l}\text { Maximal growth temperature } \\
\left({ }^{\circ} \mathrm{C}\right)\end{array}$ & 25 & $25-30$ & 30 & $25-30$ \\
\hline Glucose agar slants & $\begin{array}{l}\text { Growth as on } \\
\text { nutrient } \\
\text { agar }\end{array}$ & $\mathbf{n}$ & $\begin{array}{l}\text { Growth poorer } \\
\text { than on nutrient } \\
\text { agar }\end{array}$ & $\mathbf{n}$ \\
\hline $\begin{array}{l}\text { Milk agar plates/casein } \\
\text { hydrolysis }\end{array}$ & + & \pm & $+($ very slow $)$ & \pm \\
\hline $\mathrm{pH}$ in VP broth & $\mathbf{n}$ & $6.0-6.6$ & $\mathbf{n}$ & $6.2-7.4$ \\
\hline Starch hydrolysis & - & \pm & \pm & + \\
\hline Methylene blue reduction & + & $\mathbf{n}$ & \pm & $\mathbf{n}$ \\
\hline Nitrate reduction & - & \pm & + & + \\
\hline \multicolumn{5}{|l|}{ Acid production } \\
\hline Lactose & + & $\mathbf{n}$ & - & $\mathbf{n}$ \\
\hline Mannitol & - & - & + & \pm \\
\hline Xylose & - & - & + & \pm \\
\hline
\end{tabular}

${ }^{a}+$, All strains positive; - , all strains negative; \pm , positive and negative strains are known; $n$, not reported.

TABLE 2. Cell wall composition of B. globisporus DSM 4 and B. psychrophilus DSM $3^{a}$

\begin{tabular}{|c|c|c|}
\hline $\begin{array}{l}\text { Cell wall } \\
\text { component }\end{array}$ & $\begin{array}{l}\text { B. globisporus } \\
\text { DSM } 4\end{array}$ & $\begin{array}{c}\text { B. psychrophilus } \\
\text { DSM } 3\end{array}$ \\
\hline Alanine & +++ & $++t$ \\
\hline Glutamic acid & $++t$ & +++ \\
\hline Glycine & ++ & +++ \\
\hline Asparagine $^{b}$ & $\mathrm{Tr}$ & + \\
\hline meso-DAP & - & $\operatorname{Tr}$ \\
\hline Lysine & +++ & +++ \\
\hline Valine & $\operatorname{Tr}$ & + \\
\hline Muramic acid & + & + \\
\hline Glucosamine & +++ & +++ \\
\hline $\begin{array}{l}\text { Leucine/ } \\
\text { isoleucine }\end{array}$ & ++ & ++ \\
\hline
\end{tabular}

a Symbols:,,,$++++++ \operatorname{Tr}$ (traces), and - represent the relative amounts of substances present (or absent) on the chromatograms; in the case of the amino acids, + and $\operatorname{Tr}$ indicate negligible amounts.

${ }^{b}$ As a result of acid hydrolysis, aspartic acid instead of asparagine appeared in the chromatograms.

${ }^{c}$ meso-DAP, meso-Diaminopimelic acid.

tions (6) showed these values to be in the same range: $39.7 \pm 0.3 \mathrm{~mol} \%$ and $40.6 \pm 0.6 \mathrm{~mol} \%$ guanine plus cytosine for $B$. psychrophilus DSM 3 and $B$. globisporus DSM 4, respectively.

Because of the difficulty in differentiating between B. globisporus and B. psychrophilus, as previously discussed by Gyllenberg and Laine (3), we decided to analyze the cell walls of the type strains of these species to see if the information derived therefrom would help to clarify the relationship of these organisms. The results, presented in Table 2, showed that both strains have the same cell wall composition.

Because the type strains of $B$. globisporus and $B$. psychrophilus are very nearly identical (6), we regard them as belonging to the same species, the correct name of which is $B$. globisporus. (Although the names $B$. globisporus and $B$. psychrophilus were proposed by the same authors in the same paper, the former was proposed first, and thus has priority [page priority]. Thus $B$. psychrophilus is a later subjective synonym of $B$. globisporus.)

\section{ACKNOWLEDGMENTS}

We are indebted to T. L. Tan and to R. Simonsen for reading this manuscript.

We thank the Deutsche Forschungsgemeinschaft for supporting this work.

\section{REPRINT REQUESTS}

Address reprint requests to: Dr. Hans-Jürgen Rüger, Institut für Meeresforschung, Am Handelshafen 12, D-2850 Bremerhaven, Federal Republic of Germany.

\section{LTERATURE CITED}

1. Eiroma, M., J. J. Laine, and H. G. Gyllenberg. 1971. DNA base composition in paychrophilic and mesophilic bacilli. Ann. Med. Exp. Biol. Fenn. 49:59-61.

2. Gordon, R. E., W. C. Haynes, and C. H.-N. Pang. 1973. The genus Bacillus. U.S. Department of Agriculture, Handbook no. 427, Washington, D.C.

3. Gyllenberg, H. G., and J. J. Laine. 1971. Numerical approach to the taxonomy of psychrophilic bacilli. Ann. Med. Exp. Biol. Fenn. 49:62-66.

4. Larkin, J. M., and J. L. Stokes. 1967. Taxonomy of psychrophilic strains of Bacillus. J. Bacteriol. 94:889895.

5. Richter, G. 1977. Routine use of thin-layer chromatography for cell wall analysis of aerobic actinomycetes, including two strains from sediments of the North Sea. Veröff. Inst. Meeresforsch. Bremerh. 16:125-138.

6. Rüger, H.-J., and G. Richter. 1979. Bacillus globisporus subsp. marinus subsp. nov. Int. J. Syst. Bacteriol. 29: 196-203.

7. ZoBell, C. E. 1946. Marine microbiology. Chronica Botanica Company, Waltham, Mass. 